Table II Determination of calcium oxide and magnesium oxide in boiler scale (Results of six analyses)

\begin{tabular}{|c|c|c|c|c|c|c|c|c|}
\hline \multirow{2}{*}{\multicolumn{2}{|c|}{ Sample mark }} & \multicolumn{7}{|c|}{ Composition found $(\%)$} \\
\hline & & \multirow{2}{*}{$\begin{array}{c}\mathrm{CaO} \\
34.44 \sim 34.70 \\
34.55 \\
0.083\end{array}$} & \multirow{2}{*}{ 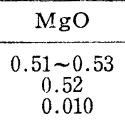 } & \multirow{2}{*}{$\begin{array}{r}\mathrm{SiO}_{2} \\
9.43\end{array}$} & \multirow{2}{*}{$\begin{array}{r}\mathrm{Fe}_{2} \mathrm{O}_{3} \\
13.69\end{array}$} & \multirow{2}{*}{$\begin{array}{c}\mathrm{Al}_{2} \mathrm{O}_{3} \\
0.94\end{array}$} & \multirow{2}{*}{$\begin{array}{l}\mathrm{P}_{2} \mathrm{O}_{5} \\
30.36\end{array}$} & \multirow{2}{*}{$\begin{array}{c}\operatorname{Ign} . \operatorname{loss} \\
9.22\end{array}$} \\
\hline Scale A & $\begin{array}{c}\text { Range } \\
\bar{x} \\
\sigma\end{array}$ & & & & & & & \\
\hline Scale B & $\begin{array}{c}\text { Range } \\
\bar{x} \\
\sigma\end{array}$ & $\begin{array}{c}21.29 \sim 21.91 \\
21.57 \\
0.221\end{array}$ & $\begin{array}{c}1.95 \sim 2.21 \\
2.02 \\
0.103\end{array}$ & 5.13 & 50.70 & 0.57 & 15.68 & 3.36 \\
\hline Scale C & $\begin{array}{c}\text { Range } \\
\tilde{x} \\
\sigma\end{array}$ & $\begin{array}{c}0.79 \sim 0.88 \\
0.85 \\
0.042\end{array}$ & $\begin{array}{c}0.19 \sim 0.25 \\
0.22 \\
0.027\end{array}$ & 4.69 & 85.34 & 0.84 & 0.93 & 6.12 \\
\hline
\end{tabular}

3 水塩結晶 $5 \mathrm{~g}$ 它加光, 加熱して約 5 分間煮沸する（こ のとき溶液の $\mathrm{pH}$ は 4.5〜 5.0 になる). 口紙 ( 5 種 B) を用いてロ過し, 温水で 2 回洗浄する. 口洗液はメスフ ラスコ（容量 $500 \mathrm{ml}$ ) に受けて保存する. 口紙をもと のビーカー上に広げ，沈殿を水で洗い落とし，程酸で溶 解する. 前と同じ操作によって塩基性酶酸塩の沈殿艺生 成させ，口別して吸着されていたカルシウム，マグネシ ウム学回収する。口液を前の口洗液に合わせて冷却し, 標線まで水を加えて振り混ぜる.

酸化カルシウムの定量：これから 100～200 $\mathrm{ml}$ 爷取 し,トリエタノールアミン $(1+1) 5 \mathrm{ml}$, 水酸化ナトリ ウム溶液 $(20 \%) \quad 5 \sim 10 \mathrm{ml}$ ，シアン化ナトリウム溶液 $(20 \%) 5 \mathrm{~m} l, \mathrm{NN}$ 指示薬の順に添加し， $M / 40$ EDTA 溶液で滴定する。

酸化マグネシウムの定量：別に $100 〜 200 \mathrm{ml}$ を分取 し,アスコルビン酸 $0.2 \mathrm{~g}$ ，トリエタノールアミン $(1+$ 1) $5 \mathrm{ml}$, アンモニア水-塩化アンモニウム緩衝溶液2 10 $\mathrm{m} l$, シアン化ナトリウム溶液 $(20 \%) 5 \mathrm{~m} l$ の順に加 え, $\mathrm{pH}$ を 10 に調節する. EBTトリエタノールアミ ン溶液（1\%） 2 滴を添加し， $M / 40$ EDTA 溶液で滴定 して酸化カルシウムと酸化マグネシウムの合量を求め, 酸化カルシウム相当量を差し引いて酸化マグネシウム量 蓬算出する。

\section{4 定量結果}

本法によって行尔ったボイラースケールの分析結果例

†ボイラースケールの分析ではほとんどの場合に酸化 脸わよび五酸化りンの定量を同時に行なう。 その結 果加ら添加する睢化第二鉄の量を次式によって決め るのがよい.しかしとれは絶対的なものではなく， 扰打よその見当を示すものである。な机計算做が、 イナスを示すときには, $\mathrm{Fe}^{3+}$ は添加しなくてもよ い.

添加する $\mathrm{Fe}^{3+}(\mathrm{mg})$ =分取した試料重量 $(\mathrm{mg})$

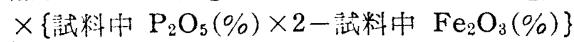
$\times 0.007$
を Table II に示す. 鉄量, カルシウム星の異なる試 料を選んで揭示した，再現精度はいずれも泉好である。

終わりに，本研究の発表を部可された秼式会社日本製 銅所室闌製作所長取締役踺和田暢男氏に感謝する。

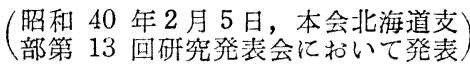

\section{交献}

1) A. M. Smith, E.S. R. Mc Callum : Analyst, 81, 160 (1956).

2）上野景平: “キレート滴定法”, p. 228 (1961), (南江堂).

(昭和 40 年 2 月 26 日受理)

\section{薄層クロマトグラフィーによる \\ 金属イオンの一斉分析-3* \\ 一湿度の影響について—}

滝谷弨司, 福阔 紀子, 岩崎 芳子，辰谷川 斉**

\section{1 緒}

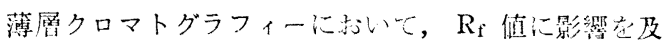
ぼす因子としては主として次の项日1) 10)をあげること

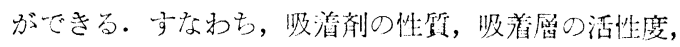

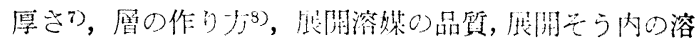

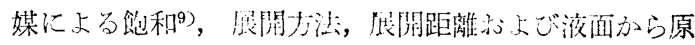
点までの距離110), 試料の最, 温度などでかる。. 無機イ

* 然機薄圈クロマトグラフィーの研究（第 6 報）

** 東宗理科大学薬学部桨品分析化学教空: 東宗都新宿 区朾ヶ谷船河原町 


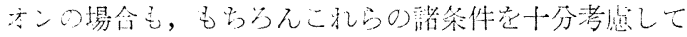

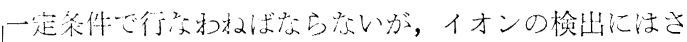

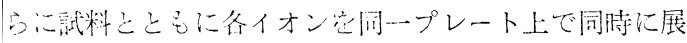

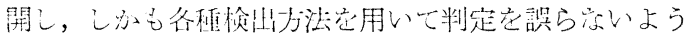

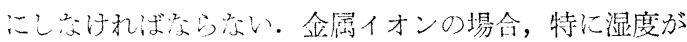
$\mathrm{R}_{\mathrm{f}}$ 值に大きく影響 一方ので，今回はこの点について若 干の检討劣行なった。

Geiss ら ${ }^{13)}$ 法薄廨クロマトグラフィーにおいて， $\mathrm{R}_{\mathrm{f}}$ 谊に及ぼす湿度（相刘湿度，以下同じ）の影響について

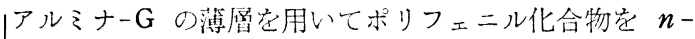
ヘプタンで馓掤したときの $\mathrm{R}_{\mathrm{f}}$ 值の变化について， $\mathrm{R}_{\mathrm{f}}$ 值 㵊大 $300 \%$ の変動があり，また湿度 30〜40\% のとき 最も分㫿がよかったこと艺報告している。湿度の影響は

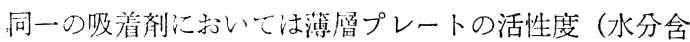
量）の変化による影欴と同一に考えられるが，いかに一 定条件下で作った薄原プレートでも活性化後の放冷，試 料の塗布など居网前の条作が一定でなければ，展開孛る ときの薄層プレートの活州度は変化するので, 当然 $\mathrm{R}_{\mathrm{f}}$ 値の变動の原因となりうる。そこで今回は，一定条件で 活性化した $5 \%$ 可溶性デン粉含有精製シリカゲルによる 薄層プレート10)各一定湿度の密閉空間中に一定時間放 置したの方，一斉分析10)11)に用いた 3 種の展開溶媒で展 開しなときの $\mathrm{R}_{\mathrm{f}}$ 值，展開時間その他の変動をニッケル， コバルト，銅，アンチモン，ビスマス，水銀，バリウ ム, ナトリウム, リチウムの各イオンについて観察した 辣果在報监与る。

\section{2 実験および結果}

\section{$2 \cdot 1$ 薄層プレート, 装置, 器具}

薄凮プレート $\left.{ }^{10}\right)$ $5 \times 20 \mathrm{~cm}$ のガラス板に, 精製シリ カゲルと絬合剤として可溶性デン粉を用いて愿さ $250 \mu$ で作り， $110^{\circ} \mathrm{C} ， 40$ 分鿒燥後，雨側のシリカゲルを 0.5 $\mathrm{cm}$ ずつけ卢りとったのち保存箱中で放冷する。次に

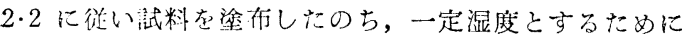
内径 $14.5 \times 22.5 \times 5 \mathrm{~cm}$ のガラスそう内の各種㷪類（穛 化互鉛，醮酸カリウム，㙁化カルシウム，硝酸再鉛，硫 酸水素ナトリウム，奥化ナトリウム，西硝酸ナトりウ ム，酢酸ナトリウム，硫酸アンモ二ウム，硫酸西鉛，硝 酸鉛）による周相の其存する跑和水溶液上の密閔空間 中14)に放間（20時間）する。ただし湿度 $0 \%$ は五酸化 リンをこのまま用いた。またててのときの笑際の各湿度 はガラスそうの横にあけた穴から湿度部*の受感部をる う入して打当测定した。

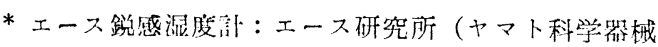
株式会社発売)。受感部は UL $(10 \sim 30 \%) ， \mathrm{~L}(20$ ～ $40 \%), \mathrm{M}(40 \sim 70 \%), \mathrm{H}(70 \sim 90 \%)$ ○ 4 種在使 用.

\section{$2 \cdot 2$ 試料, 展開溶媒, 展開方法, 検出}

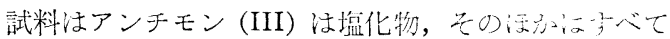

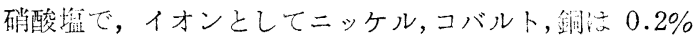
水溶液，ナトリウム，リチウム，バリウム注 $0.4 \%$ 水溶 液, ビスマスは $0.2 \%$ の $10 \%$ 硝酸溶液, 水銀 (II) は $0.2 \%$ の $1 \%$ 硝酸溶液，アンチモンは $0.2 \%$ の $10 \%$ 塩酸溶液を用いた. これらの各イオン溶液を薄層プレ一 トの下端から $2.5 \mathrm{~cm}$ の位置に $1 \mathrm{~cm}$ 間隔て約 $2 \times 10^{-4}$ $\mathrm{ml}$ 塗布後, 一定湿度の湿度箱中で一定時問放置する.

展關溶媒 ${ }^{10}$ はアセトン: $3 N$ 境酸 $(99: 1)$, メタノ一 ル : $n$-ブタノール : 濃塩酸 $(80: 10: 10), n$-ブタノ一 ル：ベンゼン： $1 N$ 硝酸 : $1 N$ 塩酸 (50: $46: 2.7: 1.3)$. 展開そうは内径 $14.5 \times 22.5 \times 5 \mathrm{~cm}$ の横型展開そうでこ れを回転台 ${ }^{12}$ （展開そうの上端の高さは $4 \mathrm{~cm}$ )にのせ傾 斜させる、薄層プレート注高さ $2 \mathrm{~cm}$ のガラス台上に上 端をのせ，下端にはガラス棒を抢く10)。展開溶媒は 30 $\mathrm{ml}$ とし, 展開をうのふたにはワセリンをつけて気密を 保つ、展開距離注原点から $12 \mathrm{~cm}$. なお本実験はすべて 室温 $23^{\circ} \mathrm{C} \pm 2^{\circ} \mathrm{C}$, 室湿度 $30 \pm 2 \%$ の条件で行なった。 各イオンの検出方法注既報10)と同様である.

\section{$2 \cdot 3$ 湿度と $\mathrm{R}_{\mathrm{f}}$ 值および展開時間}

$2 \cdot 1$ のとおり一定条件で作った薄層プレートに試料学 塗布し, 各湿度の湿度箱中に 20 時間放置後, 剭開 30 分 前に屍開溶媒を入れておいた展開そう内にすみやかに入 れ，原点加ら $12 \mathrm{~cm}$ 展開与る。 そのときの各湿度と $\mathrm{R}_{\mathrm{f}}$ 值および展開時間の結果は Fig. 1 に示す. 3 種の展開 溶媒のいずれの場合も，湿度が $80 \%$ 以上になると溶媒 先端は不明りょうになる。アセトンー塩酸ではニッケル は湿度 50\% 以下ではコンパクトなスポットであるが， それ以上ではテイリングし，特に $80 \%$ 以上では $\mathrm{R}_{\mathrm{f}}$ 值 0.05〜0.5ぐらいまでティリングする. また，コバルト は 50\% 以上の湿度では上方にティリングする。銅，コ バルトは湿度の上杽とは逆に $\mathrm{R}_{\mathrm{f}}$ 值は小さくなるが, 二 ッケルは逆にやや大きくなる傾向があり，前述のように テイリングが激しくなる。

メタノールーブタノールー㙫酸ではナトリウム，リチウ ム注混度の上昇と逆に $\mathrm{R}_{\mathrm{f}}$ 值は小さくなるが，バリウム は $50 \%$ 以上で朔に $\mathrm{R}_{\mathrm{f}}$ 值は大となり，またスポット もコンパクトになりテイリングはみられなくなる。湿度 $90 \%$ 以上では 3 者亡も $\mathrm{R}_{\mathrm{f}}$ 值 $0.3 \sim 0.4$ に沵る.

ブタノールーベンゼンー硝塩酸では水銀はあまり湿度の 影響は受けないが，70\% 以上になるこ $\mathrm{R}_{\mathrm{f}}$ 值は小さく なり下方にティリングする。亦た 3 者の六かではビスマ スは湿度による影響分最も火きく，50\%ぐらいから急 


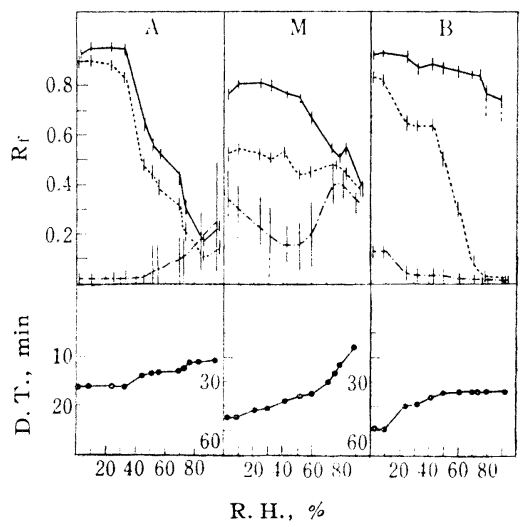

Fig. 1 Relative humidity (R. H.) of plates, $R_{f}$ value and developing time (D. T.)

Developer

A : Acetone $-3 N \mathrm{HCl}(99: 1)$

$+\mathrm{Cu}^{2+}++\cdot+\mathrm{Co}^{2+}+\cdot+\mathrm{Ni}^{2+}$

$\mathrm{M}$ : Methanol- $n$-Butanol-conc. $\mathrm{HCl}(80: 10: 10)$

$+\mathrm{Li}^{+}++\mathrm{Na}^{+}+\cdot+\mathrm{Ba}^{2+j}$

B : $n$-Butanol-Benzene- $1 N \mathrm{HNO}_{3}-1 \mathrm{~N} \mathrm{HCl}$

$(50: 46: 2.7: 1.3)$

$+\mathrm{Hg}^{2+}++\mathrm{Bi}^{3+}+\cdot+\mathrm{Sb}^{3+}$

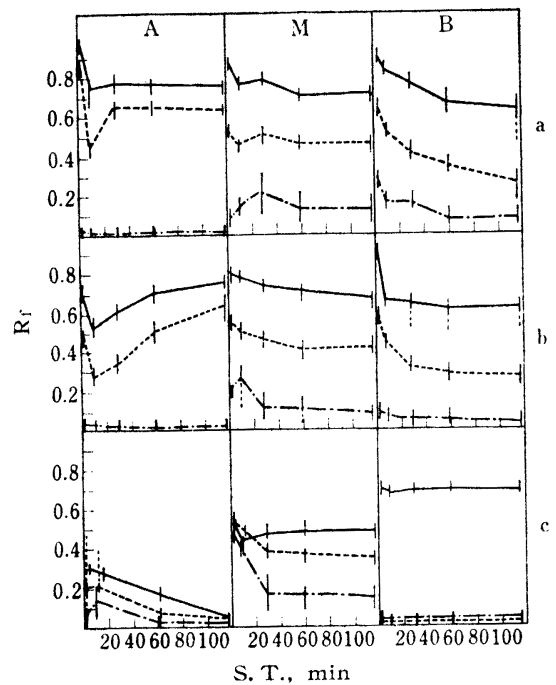

Fig. 2 Saturation time (S. T.) and $R_{i}$ value Developer

A : Acetone-3N HCl $(99: 1)$ $+\mathrm{Cu}^{2+}++\mathrm{Co}^{2+}+\cdot+\mathrm{Ni}^{2+}$

M : Methanol-n-Butanol-conc. $\mathrm{HCl}(80: 10: 10)$ $\mathrm{H} \mathrm{Li}^{+}+\cdots \mathrm{Na}^{+}++\mathrm{Ba}^{2+}$

B : $n$-Butanol-Benzene- $1 N \mathrm{HNO}_{3}-1 \mathrm{~N} \mathrm{HCl}$ $(50: 46: 2.7: 1.3)$

$+\mathrm{Hg}^{2+}+\ldots \cdot \mathrm{Bi}^{3+} \quad+\cdot+\mathrm{Sb}^{3+}$

a : Relative humidity of plate, $26 \pm 2 \%$

b: " $\quad 43 \pm 2 \%$

c : $\quad$ " $73 \pm 2 \%$
に $\mathrm{R}_{\mathrm{f}}$ 值怟下し $80 \%$ 以上になると原点となる。以上

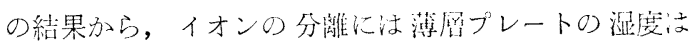

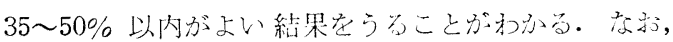
3 種の溶㷊はいずれも淐度が大に次るにしたがい展閒時 間矤く注る。

\section{$2 \cdot 4$ 飽和時間と $\mathrm{R}_{\mathrm{f}}$ 值および展開時間}

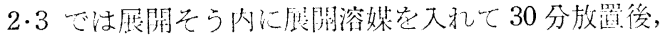
薄層プレートを入れて展间したが，このとき展開とうの ふたをとるために，九う内の館和度は低下与当 $(2 \cdot 5)$. そこで，薄層プレート学入れてからさらに一尘時间飽和

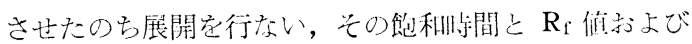
展開時間との関係を，湿度 $26 \pm 2 \%, 43 \pm 2 \%, 73 \pm 2 \%$ の3種の薄層プレートについて检討した結果を Fig. 2,

Fig. 3 に示す.

いずれの場合でも展開前に蜋開そう内を溶媒で飽和し ておいても，プレートを入れてすぐ㞗閏すると $\mathrm{R}_{\mathrm{f}}$ 値の 変動が大きくまた分離もわるい場命があり，や゙はりプレ 一トを大れてから 30〜60 分間放淮後に展開するのがよ いこと，また当然のことながら展聞時間汹飽和時間とは 逆に短くなるととが示さ机ている。

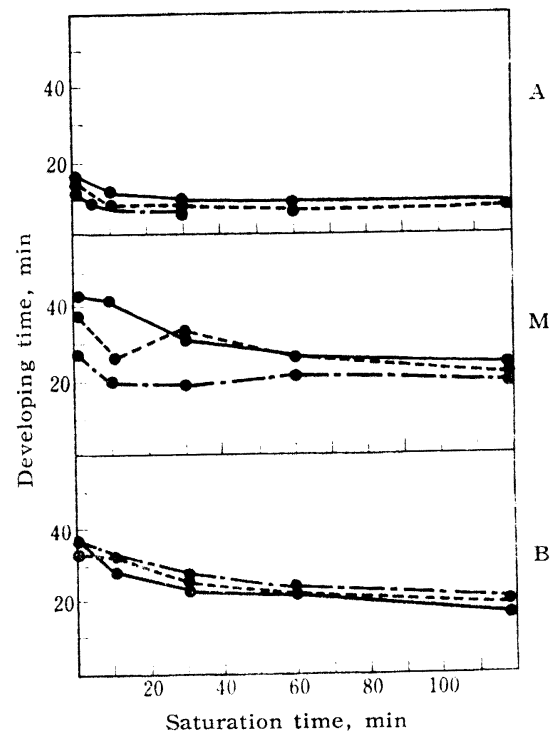

Fig. 3 Saturation time and developing time Developer

A : Acetone $-3 N \mathrm{HCl}(99: 1)$

$\mathrm{M}$ : Methanol-n-Butanol-conc. $\mathrm{HCl}(80: 10: 10)$ B : $n$-Butanol-Benzene- $1 N \mathrm{HNO}_{3}-1 N \mathrm{HCl}$ $(50: 46: 2.7: 1.3)$

$-26 \pm 2 \%$ (Relative humidity.of plate)
$-43 \pm 2 \%($ 


\section{5 展開そう内の湿度変化}

3 種の展開溶媒について 2.4 と同じく 3 種の湿度のプ

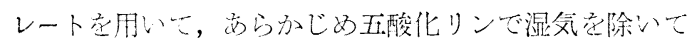

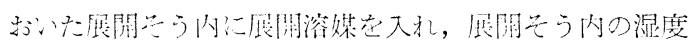

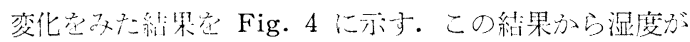

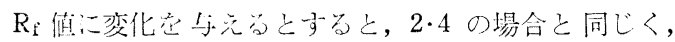

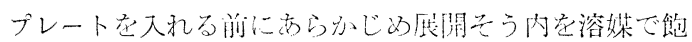

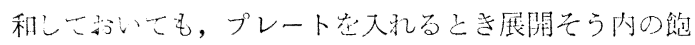
和活乱礼るのでやはりプレートを入礼てから 30〜60 分 間流放置後展開与るのが望ましいととがわかる。

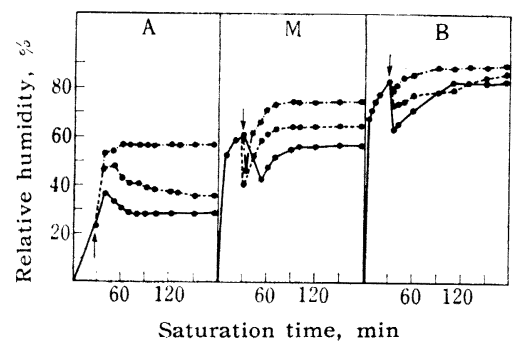

Fig. 4 Saturation time and relative humidity in developing chamber

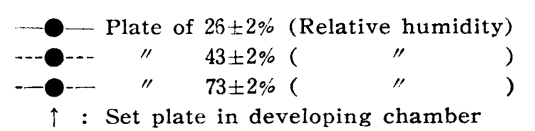
Developer

A : Acetone $-3 N \mathrm{HCl}(99: 1)$

M : Methanol-n-Butanol-conc. HCl $(80: 10: 10)$

B : $n$-Butanol-Benzene- $1 N \mathrm{HNO}_{3}-1 \mathrm{~N} \mathrm{HCl}$ $(50: 46: 2.7: 1.3)$
終わりに，然験化協力された大宮获幸，中山正大，和 栗八重子の諸君に感謝守る。

\section{文献}

1) M. Brenner, A. Niederwieser, G. Pataki, A. Fahmy : Experientia, 18, 101 (1962).

2) M. Brenner, A. Niederwieser, G. Pataki, R. Weber : E. Stah1, "Dünnschicht-Chromatographie”, S. 106 (1962), (SpringerVerlag).

3）原 昭二, 石川正幸, 古谷 力, 中沢泰男: “薄 居クロマトグラフィー”, p. 58 (1963)，（南山 堂).

4）原 昭二：“薄冏クロマトグラフィー”，第 1 集, p. 8 (1964), (南江堂).

5) M. Brenner, G. Pataki : Helv. Chim. Acta, 44, 1420 (1961).

6) T. Brodasky: Anal. Chem., 36, 996 (1964).

7) G. Pataki, M. Keller : Helv. Chim. Acta, 46, 1054 (1963).

8) G. Pataki, J. Kelemen : J. Chromatog., 11, 50 (1963).

9) C. Honegger : Helv. Chim. Acta, 46, 1730 (1963).

10）流谷昭司, 深沢乏于子, 長谷川 斉: 本誌, 12, 1156 (1963).

11）潼谷昭河, 福岡紀子, 岩崎芳子, 長谷川 斎: 同 上, 13, 469 (1964).

12）川鍋康治，滝谷昭司，宮崎元一，田村善蔵：同 上, 13, 976 (1964).

13) F. Geiss, H. Schlitt : Naturwissenschaften, 50, 350 (1963).

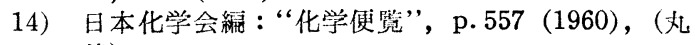
善).

（明和 40 年 3 月 8 日受理） 